\title{
INTERNATIONAL RELATIONS AS CONSTITUTIONAL MATTER IN REPUBLIC OF MACEDONIA
}

\author{
Aneta Stojanovska-Stefanova ${ }^{*} \&$ Drasko Atanasoski ${ }^{* *}$
}

Foreign policy and international relations of each country are conditioned with its internal policy and with the basic features of the political system. Besides, the principles and objectives of the foreign policy and international relations are expression and effect of its internal politics, i.e., the basic social relations that determine the physiognomy and character of the basic political institutions, and the content and purposes of the political decisions. Chapter VI of the Constitution of the Republic of Macedonia is dedicated to the issue whereby clearly and unequivocally is indicated that, for proper functioning of the democratic state, it is important how the internal as well as the issues of the international relations are regulated.

INTRODUCTION 1015

I. COMPETENCES IN THE AREA OF THE FOREIGN POLICY UNDER THE CONSTITUTION OF THE REPUBLIC OF MACEDONIA FROM 1991 1017

II. COMPETENCES IN THE FIELD OF THE FOREIGN POLICY IN ACCORDANCE WITH THE CONSTITUTION OF THE REPUBLIC OF MACEDONIA FROM 1991 .1019 III. LAW ON FOREIGN AFFAIRS FROM 2006 1020

IV. The Assembly of the RePublic OF MACEDONIA AND Foreign POLICY

V. THE GOVERNMENT OF THE REPUBLIC OF MACEDONIA AND ForEIGN POLICY 1022

VI. MinistRY OF ForeIgn AfFAIRS AND ForEIGN POLICY ....................... 1023

VII. THE Minister of Foreign AfFAiRS AND Foreign POLICY................ 1024

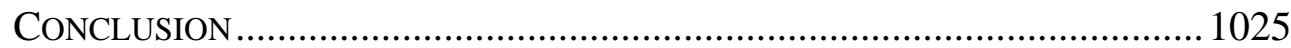

\section{INTRODUCTION}

In any democratic country, it is equally important to regulate and develop the internal and international relations.

"Macedonia is a parliamentary democracy which has a clear model of the triple division of power. The Foreign policy is a domain, constitutionally

\footnotetext{
* Aneta Stojanovska-Stefanova, PhD Candidate, Teaching Assistant, Faculty of Tourism and Business Logistics, University Goce Delcev, Stip, Republic of Macedonia. Research fields: International Law and politics; History of diplomacy; Political Systems.

${ }^{* *}$ Drasko Atanasoski, Ph.D., Assistant Professor,Faculty of Tourism and Business Logistics, University Goce Delcev, Stip, Republic of Macedonia. Research fields: International Transport and Logistics; Customs Administrative Procedure.
} 
reserved for the head of the state, the Assembly and the Government. In practice, the head of the state performs a little more powers than it is usual in the parliamentary systems, while the government performs the essential functions in the foreign policy, while the Government performs the basic functions of the foreign policy, leaving the Assembly in a rather weaker position."1

"The political, legal, economic and cultural traffic between the subjects of the international law is going through their authorized representatives and through their bodies."

The Republic of Macedonia has dedicated the Chapter VI of the Constitution to the regulation of this matter.

"The international relations are subject to the regulation of the constitutional regulation because the internal law depends on the international law.

The best proof of this are those constitutes that contain provisions for the transfer of part of the national sovereignty over the international institutions, or stipulating consent for accordance of the internal legal order with the generally accepted rules of the international law. The dependence of the internal law of the international law is in function of the actions of the independent states in the field of protection and promotion of the world peace." ${ }^{3}$

The main sources of the international relations are the mandatory norms of the international law ("jus cogens") and the legal principles recognized by civilized nations.

"With the mandatory norms of the international public law and legal principles recognized by the civilized nations, the international relations of the states become legal relations or values that are developed with the help of the law. In such a context, the right appears as a factor of civilized development of the international relations." ${ }^{4}$

The rules of the international public law are often violated, especially this phenomenon is noticeable in time of war when "the strong do what they have power to do, and the weak do what they must accept." ${ }^{5}$

"The constitution of the Republic of Macedonia from 1991 regulates the international relations with the two types of provisions.

\footnotetext{
${ }^{1}$ Mirchev Dimitar, The Macedonian Foreign Policy 1991-2006 20 (Skopje, Az-buki 2006).

${ }^{2}$ FrChKoski Ljubomir, InTERnational Public LAW 185 (Tabernakul, Skopje 1995).

${ }^{3}$ ShKARIKJ S. \& SilJANOVSKA-DAVKOVA G., Constitutional LAw 607 (Skopje: Faculty of Law "Iustinianus Primus" 2007).

${ }^{4}$ ShKarikJ S. \& SiljanovsKa-Davkova G., Constitutional Law 608 (Skopje: Faculty of Law

"Iustinianus Primus" 2007).

${ }^{5}$ TUKIDIT, History 344-350 (Adomir, Moscow 1981).
} 
First, the international relations are evaluated from the perspective of the generally accepted norms of the international law, as a fundamental value of the constitutional order of the Republic of Macedonia and second, with several provisions, contained in a separate section of the normative text of the Constitution.

By accepting the generally accepted norms of the international law as a fundamental value, the Republic of Macedonia is committed to respect the sources of the international law: the international customary law; practice of international courts; doctrine or opinion of respectable experts in the field of the international law and ratified international agreements. In the section, dedicated to the international relations are regulated several groups of issues: the relation of the ratified agreements against the internal legal order of the Republic of Macedonia; entities responsible for the concluding of the international agreements; association and dissociation of the Republic of Macedonia from alliances or communities with other countries and deciding on association and dissociation of the Republic of Macedonia from membership in international organizations ${ }^{6}$.

The international agreements ratified in accordance with the Constitution are part of the internal legal order in the Republic of Macedonia and they cannot be changed by law. With this solution, the ratified international agreements; association and dissociation of the Republic of Macedonia from alliances or communities with other states and decides on association and dissociation of the Republic of Macedonia from membership in the international organizations."

\section{COMPETENCES IN THE AREA OF THE Foreign POLICY UNDER THE CONSTITUTION OF THE REPUBLIC OF MACEDONIA FROM 1991}

The latter principle of the fundamental values of the constitutional order of the Republic of Macedonia is respect of the generally accepted norms of international law. Namely, with the belonging of the international community, each state as a unitary and federal falls under the authority of the rules or standards of behavior that are built in that community.

Foreign policy and international relations of each country are conditioned with its internal policy and with the basic features of the political system. Besides, the principles and objectives of the foreign policy

\footnotetext{
${ }^{6}$ Aneta Stojanovska, Constitutional-Legal and Political Aspects of the Foreign Policy, with Special Retrospection to Republic of Macedonia, MASTER THESIs, 41.

${ }^{7}$ SHKARIKJ S. \& SiLJANOVSKA-DAVKOVA G., Constitutional LAw 609 (Skopje: Faculty of Law “Iustinianus Primus”, University “Ss. Cyril and Methodius” 2007).
} 
and international relations are expression and effect of its internal politics, i.e., the basic social relations that determine the physiognomy and character of the basic political institutions, and the content and purposes of the political decisions.

Chapter VI of the Constitution of the Republic of Macedonia is dedicated to the issue whereby clearly and unequivocally is indicated that, for proper functioning of the democratic state, it is important how the internal as well as the issues of the international relations are regulated.

As a peaceful, independent and sovereign state, the Republic of Macedonia is fighting for international relations based on:

1. respect of the national sovereignty and equality of all people and countries;

2. non-interference in the sovereign rights of other countries and in their internal affairs;

3. settlement of the international disputes with dispatch with clear statement that it has no territorial claims against neighboring countries;

4. acceptance and fulfillment of its international obligations;

5. active participation in the activities of the international organizations to which wants to join and;

6. compliance with the principles of the Charter of the United Nations. ${ }^{8}$

Apart from the Constitution as the highest act, the issues of the international relations are regulated by the Law on Foreign Affairs, Law on Signing and Ratification and Enforcement of the International Agreements.

The Constitution undertakes the traditional provision, present in many constitutions in the world that build a system of parliamentary democracy, according to which the international agreements in the name of the Republic of Macedonia are concluded by the President of the Republic of Macedonia. Thereto, the Constitution gives possibility to the Government of the Republic of Macedonia to conclude international agreements when it is determined by law (Article 119).

But much more important are the provisions of the Constitution that govern issues for entering into a union or community with other states, or dissociation from a union or community with other states. As holders of the proposal for association or dissociation from a union or community with other states, the Constitution strictly lists: 1 . The President of the Republic, 2. The Government, or 3. At least 40 MP's.

This proposal they submit to the Assembly of the Republic of Macedonia which the decision for association or dissociation from a union

\footnotetext{
${ }^{8}$ Klimovski S., Constitutional and Political System 469-470 (Prosvetno delo AD Skopje 2001).
} 
or community with other states adopts by qualified, i.e., two-thirds majority from the total number of the MP's. But this procedure is not completed with that. The decision adopted by the Assembly is considered for adopted if on a referendum voted for it the majority of the total number of voters (Article 120).

The constitution envisages a shorter procedure when it comes to entering into membership or cancellation of membership in international organizations. In this case also, the decision on entering or cancellation of a membership in the international organizations adopts the Assembly of the Republic of Macedonia by a majority vote from the total number of MPs, and holder of the proposal is the President of the Republic, the Government, or at least 40 Members of the Parliament (Article 121). ${ }^{9}$

\section{COMPETENCES IN THE FIELD OF THE FOREIGN POLICY IN ACCORDANCE WITH THE CONSTITUTION OF THE REPUBLIC OF MACEDONIA FROM 1991}

According to the Constitution of the Republic of Macedonia, and according to the character whether the conduct of the foreign policy is one of the major responsibilities, authorities for performing foreign affairs can be divided into two groups: primary and secondary.

Primary are those authorities that are focused on the major responsibilities in the execution of the foreign policy and here belong the following:

1. The President of the Republic of Macedonia;

2. The Assembly of the Republic of Macedonia;

3. The Government of the Republic of Macedonia;

4. The Ministry of Foreign Affairs and;

5. The Minister for Foreign Affairs.

Secondary however are, those authorities and institutions which in certain cases and circumstances may participate in the conduct of the foreign policy and here belong the following:

1. Authorities of the state government; and

2. The units of the local self-government.

In the area of the foreign policy, the President of the Republic of Macedonia has the following responsibilities:

- Appoints and dismisses by decree the ambassadors and MP's of the Republic of Macedonia abroad;

- Accepts the credentials and revocable letters of the foreign diplomatic representatives.

\footnotetext{
${ }^{9}$ Klimovski S., Constitutional and Political System 472 (Prosvetno delo AD Skopje 2001).
} 
The Assembly of the Republic of Macedonia has the following responsibilities:

- Ratifies international agreements;

- Makes decisions on association and dissociation from a union or community with other states.

While the Government of the Republic of Macedonia has the following responsibilities:

- Decides on recognition of states and governments;

- Establishes diplomatic and consular relations with other countries;

- Adopts decisions on opening of diplomatic and consular offices abroad;

- Proposes appointment of ambassadors and MP's of the Republic of Macedonia abroad and appoints heads of consular offices.

"Conventionally, the authorities responsible for international relations can be divided into two groups:

(1). State authorities whose headquarters is in the state (or internal authorities); and

(2) Authorities whose headquarters is in the territory of other countries (foreign authorities).

The first group includes the: Head of State (monarch or president of Republic), the President of the Government (Prime Minister), and the Minister for Foreign Affairs.

The second group includes the diplomatic and consular representatives and the permanent representatives of the countries in the international organizations."10

\section{LAW ON FOREIGN AFFAIRS FROM 2006}

With the Law on Foreign Affairs ${ }^{11}$ precisely are defined, the responsibilities of authorities for performing of the foreign work. With the same prescriptive in details normatively is determined the whole process of creation, establishment and implementation of the foreign policy, as well as the relations between the authorities conducting foreign affairs and the state government authorities, in the exercising of the foreign affairs, which reduces the possibility of overlapping or dysfunction. Characteristic of the Law on Foreign Affairs of the Republic of Macedonia is that, besides the traditional approach towards creating such a norm, it emphasizes the role of the Assembly of the Republic of Macedonia.

\footnotetext{
${ }^{10}$ FrchKoski LjubomiR, InTERnAtional Public Law 185 (Tabernakul, Skopje 1995).

${ }^{11}$ Law on Foreign Affairs, Official Gazette of the Republic of Macedonia 46/06.
} 
Also, by the law, it is determined the jurisdiction, structure and operation of the Ministry of Foreign Affairs, which before the adoption of the law was governed by one member of its competence and the Law on the organization and operation of the state administration authorities, i.e., some members in the same law for competences of the management authorities. The great part of the matter for the essential elements of the organization and work of the Ministry before the adoption of the law were moved bylaws.

Furthermore, the law defines the diplomatic and consular representations that Republic of Macedonia can open abroad, and the procedure and conditions of appointment of the head of the diplomaticconsular office. More precisely is determined the procedure for revocation of the heads of the missions, and their duties, responsibilities and relations with the authorities for performing of the foreign works. Determined are specific duties and diplomatic-consular officers working in diplomaticconsular offices.

The Law on Foreign Affairs in Article 2, precisely determines and delimits the terms foreign affairs and foreign policy.

The term "foreign affairs" refers to actions performed by the competent authorities of the state government, and the state government management in the exercise and protection of the rights and interests of the Republic of Macedonia in the international relations with the countries, international authorities, organizations and communities.

While the term "foreign policy" refers to political objectives and activities of the Republic of Macedonian relations with countries and with international authorities, organizations and communities that protects the interests of the Republic of Macedonia in the international relations and protect the interests of its citizens and the legal entities registered in it ${ }^{12}$.

\section{The Assembly of the Republic of Macedonia And Foreign Policy}

According to the Article 6 of the Law on Foreign Affairs, the Assembly of the Republic of Macedonia determines the foreign policy of the Republic of Macedonia, including the issues of the international relations with implications for security and defense; at their request or at the request of the Government, reviews reports on realization of the foreign policy and international position of the Republic of Macedonia, including security and defense issues at the international plan; takes positions on an

\footnotetext{
${ }^{12}$ Aneta Stojanovska, Constitutional-Legal and Political Aspects of the Foreign Policy, with Special Retrospection to Republic of Macedonia, MASTER THESIS, 27.
} 
issue on the proposal of the Government, including those on foreign-policy issues related to security and defense; with different views on matters of foreign affairs, at the proposal of the Ministry, on behalf of the Government or on the proposal of the President, the Assembly debates on these issues, after what adopts appropriate conclusions; the working body of the Assembly responsible for foreign policy at least twice a year reviews report of the Minister, on the implementation of the foreign policy and realization of the international cooperation in the framework of its powers.

\section{THE GOVERnMENT OF THE REPUBLIC OF MACEDONIA AND ForEIGN POLICY}

According to the provisions of the Law on Foreign Affairs, the Government has extensive competencies in the area of the foreign policy. Namely, in accordance with Article 7 of the Law on Foreign Affairs, the Government of the Republic of Macedonia, participates in the creation of the foreign policy by establishing the general guidelines for the foreign policy in cooperation with the President, including issues of the international relations with implications upon security and defense of the country; informs the Assembly on issues of foreign policy and international relations; at the request of the Assembly, submits a report on the realization of the foreign policy and for international position of the Republic of Macedonia, including security and defense issues at the international level; monitors the implementation of the foreign policy, and the results and eventual disagreements with other bodies for foreign affairs could notify the Assembly; shall submit to the President opinions and suggestions on international issues; to establish, develop and promote political, economic or financial relations with one or more countries or international governmental or non-governmental organizations and informs the Assembly for that; proposes the appointment and dismissal of ambassadors, envoys and appoints and dismisses heads of consular offices of the Republic of Macedonia abroad, in accordance with this Law; issues agreement or exequatur for the heads of foreign diplomatic and consular offices; decides on opening of diplomatic-consular offices and other offices of the Republic of Macedonia and for opening of foreign diplomatic-consular representative offices or offices on international organizations in the Republic of Macedonia, in the procedure determined by this Law; decides on the participation of the Republic of Macedonia in the Common Foreign and Security Policy and the European Security and Defense Policy of the European Union; provides funds within the Budget of the Republic of 
Macedonia for emergency and unforeseen situations that arise within the frames of the implementation of foreign policy; provides funds in the budget to compensate the cost of fees and other expenses arising from the membership and participation of the Republic of Macedonia in the international governmental organizations; regularly monitors and evaluates the international relations that have implications on the security and defense and shall inform the President and Assembly for that; provides relief operations in which participates the Republic of Macedonia to be coordinated with those of the international organizations and appoints honorary consuls in proceedings determined by this Law.

\section{Ministry OF Foreign AfFAIRS AND ForeIGN POLICY}

According to the Law of Foreign Affairs, the Ministry of Foreign Affairs, represents and promotes the Republic of Macedonia and develops and coordinates the bilateral and multilateral relations and cooperation with other countries and international organizations; conducts the foreign policy; ensures coordination between the competent authorities for foreign affairs in the performance of foreign affairs; conducts a procedure for the establishment and termination of diplomatic and consular relations with other countries, as well as the procedure to join and establish relations with international organizations; protects the interests, rights and property of the state and its citizens and legal persons abroad; undertakes activities related to the implementation of the decisions of the Security Council of the United Nations concerning the restrictive measures, adopted in accordance with the provisions of Chapter 7 of the UN Charter; coordinates the participation of the Republic of Macedonia in the Common Foreign and Security Policy and the European Security and Defense Policy of the European Union; provides coordination of the foreign-policy aspects of the participation of the Republic of Macedonia to the missions and operations to maintain international peace and security; monitor the development of the international economic relations and proposes; appropriate decisions to the competent authorities; cares for the status and rights of the Macedonian people in the neighborhood; cares for the status and human rights of the communities minorities, citizens of the Republic of Macedonia abroad; cares for the status and human rights of the citizens of the citizens in the Republic of Macedonia that temporarily or permanently reside abroad as well for the expatriates; organizes and manages the diplomatic-consular and other offices of the Republic of Macedonia and organizes the system of relations with them; participates in the signing, preparation and ratification 
and keeping of the international conventions to which has joined the Republic of Macedonia; monitors and contributes to the development of the international relations and international law; determines and marks the border, maintains and renews the border markers and participates in the solution of the border incidents; proposes and implements the visa policy and the visa regime of the Republic of Macedonia; manages with the Visa Center and with the Visa Information System by which provides connectivity to all segments in the implementation of the visa regime of the Republic of Macedonia; communicates and coordinates the cooperation with the foreign diplomatic and consular offices and with the missions of the international organizations in the Republic of Macedonia; manages the accreditation procedure and the procedure on the credentials of the foreign ambassadors, the procedure for recognition of the privileges and immunities of the foreign diplomatic offices and on offices of the international organizations, in accordance with the international law; proposes, prepares and conducts the procedure for appointment and dismissal of the heads of the diplomatic and consular offices of the Republic of Macedonia; conducts the procedure for rental, purchase, construction and maintenance of the real estate in other countries for the diplomatic and consular offices of the Republic of Macedonia; collects and keeps domestic and foreign documentation in the field of foreign policy and the international relations of the Republic of Macedonia in the diplomatic archives of the Ministry; informs the President of the most important issues in the realization of the foreign policy of the country and gives opinions and suggestions in relation to the foreign policy issues within its jurisdiction, including security and defense aspects arising from the international relations; participates in the development and application of the acts and initiatives of the President, pursuant to the authority of the Ministry; cooperates with associations of citizens and with scientific institutions; coordinates the implementation of the political views on participation in operations to maintain the international peace and security, in cooperation with the relevant ministries and performs other duties determined by Law.

\section{The Minister of Foreign Affairs AND Foreign Policy}

According to the Law on Foreign Affairs, the powers of the Minister of Foreign Affairs prescribed in the Article 9, by which the Minister participates in the creation of the foreign policy by proposing of the general guidelines of the foreign policy, including the issues of the international relations with implications on the security and defense of the country; 
proposes views of the area of the foreign policy and gives opinions in the field of the foreign affairs and international relations; implements the established foreign policy; within their jurisdictions, leads and conducts the political dialogue with international actors in the name of the Republic of Macedonia; represents the views of the state to international organizations and international conferences; before the working body of the Assembly competent for foreign policy, at least twice a year, submits report on the implementation of the foreign policy and international position, including the security and defense issues at the international level; at the request of the Assembly, submits report on the implementation of the foreign policy and international position, including the security and defense issues at the international level and at the request of the Assembly or at the proposal of the Government, explains the attitudes and actions of the Government on issues of foreign policy, including issues of the international relations with implications for security and defense of the country and for the progress in the implementation of the foreign policy ${ }^{13}$.

\section{CONCLUSION}

Republic of Macedonia is a parliamentary democracy which has a clear model of the triple division of power. The Foreign policy is a domain, constitutionally reserved for the head of the state, the Assembly and the Government. The Republic of Macedonia has dedicated the Chapter VI of the Constitution to the regulation of this matter. According to the Law of Foreign Affairs, the Ministry of Foreign Affairs, represents and promotes the Republic of Macedonia and develops and coordinates the bilateral and multilateral relations and cooperation with other countries and international organizations.

According to the Law on Foreign Affairs, the powers of the Minister of Foreign Affairs prescribed in the Article 9, by which the Minister participates in the creation of the foreign policy by proposing of the general guidelines of the foreign policy including the issues of the international relations. The working body of the Assembly competent for foreign policy, at least twice a year, submits report on the implementation of the foreign policy and international position, including the security and defense issues at the international level. The international agreements ratified in accordance with the Constitution are part of the internal legal order in the Republic of Macedonia and they cannot be changed by law.

\footnotetext{
${ }^{13}$ Ibid. at 35-37.
} 